This is the peer reviewed version of the following article: Archer $D, O^{\prime} D o n n e l l ~ G$, Lamb $R$, Warren S, Fowler HJ. Historical flash floods in England: New regional chronologies and database. J Flood Risk Management. 2019;e12526. https://doi.org/10.1111/jfr3.12526, which has been published in final form at https://doi.org/10.1111/jfr3.12526. This article may be used for non-commercial purposes in accordance with Wiley Terms and Conditions for Use of Self-Archived Versions.

\title{
Historical flash floods in England: new regional chronologies and database
}

David Archer ${ }^{1,2}$, Greg O'Donnell ${ }^{1}$, Rob Lamb ${ }^{2,3}$, Sarah Warren ${ }^{2}$, Hayley J. Fowler ${ }^{1}$

1. Water Resource Systems Research Laboratory, School of Engineering, Newcastle University, UK, NE1 7RU

2. JBA Trust, South Barn, Broughton Hall, Skipton, North Yorks., BD23 3AE, UK

3. Lancaster Environment Centre, Lancaster University, LA1 4YQ, UK

Corresponding author:

Greg O'Donnell

Department of Engineering

Newcastle University

Newcastle upon Tyne, UK

NE1 7RU

Email: g.m.odonnell@ncl.ac.uk

\begin{abstract}
There is increasing interest in past occurrences of flooding from intense rainfall, commonly referred to as 'flash flooding', and the associated socioeconomic consequences. Historical information can help us to place recent events in context and to understand the effect of low frequency climate variability on changing flash flood frequencies. Previous studies have focussed on fluvial flooding to reconstruct the temporal and spatial patterns of past events. Here, we provide an online flood chronology for the north and south-west of England for flash floods, including both surface water and fluvial flooding, with coverage from $\sim 1700$ to 2013 (http://ceg-fepsys.ncl.ac.uk/fc). The primary source of documentary material is local newspaper reports, which often give detailed descriptions of impacts. This provides a new resource to inform communities and first responders of flood risks, especially those from rapid rise in water level whose severity may be greater than those of accompanying peak flow. Examples are provided of historical flash floods that exemplify how the chronologies can help to place recent floods in the context of the pre-instrumental record for: (1) more robust estimates of event return period, (2) identification of catchment or settlement susceptibility to flash flood events, (3) characterisation of events in ungauged catchments.
\end{abstract}

Keywords: extreme events; flash flood; flood chronologies; historical hydrology 


\section{Introduction}

River flow archives typically provide the most readily available source of information regarding past flood events. However, many national gauging networks were not established until the mid- $20^{\text {th }}$ Century (Hall et al., 2015; Mishra and Coulibaly, 2009), with a focus on mesoscale and larger catchments. Over the last forty years there has been increasing interest in historical hydrology, with the use of documentary archives to temporally extend knowledge of the incidence of flood events, assess the role of climatic variability and to place recent large floods into a historical perspective (Brázdil et al., 2006). A major focus has concerned fluvial flood events, in particular on developing methods to quantify peak water levels and peak flows in the pre-instrumental period (e.g. Bayliss and Reed, 2001; Benito et al., 2004; Leese, 1973; Macdonald and Sangster, 2017; O'Connell et al., 1998; Stedinger and Cohn, 1986; Wetter, 2017). Reporting on the incidence of historical surface water and flash flood events in ungauged catchments has received much less attention.

Historical descriptions of floods are clearly less precise than river gauge data and associated measurements and observations of recent flood levels. However, historical descriptions can often provide good details of water levels in extant buildings and flood extent which can be compared with more recent observation. This potentially allows the investigation of whether recent large floods have historical precedents, thereby providing a better indication of rank and hence probability of occurrence (e.g. Archer et al., 2017). However, consideration is required of historical changes in channel conditions. A potential limitation of newspaper articles is the lack of a consistent standard for reporting flood events, both in terms of the selection of events and details provided, and a bias towards urban areas. However, the provision of information from ungauged catchments and surface water flooding, which are rarely reported by national hydrological agencies, with good temporal dating, provide a valuable resource.

Within the UK, previous partial compilations of flood histories have been made on the basis of epigraphic flood markers (Macdonald, 2007; NERC, 1975), historical documents (Potter, 1978) and historical newspaper accounts for a limited region (Archer, 1992). The Chronology of British Hydrological Events (http://cbhe.hydrology.org.uk/) now provides a reasonably comprehensive record of historical fluvial flood events throughout Great Britain up until 1930, with scattered records thereafter (Black and Law, 2004). Macdonald and Sangster (2017) also provide a national analysis of spatial and temporal flooding since 1750, with an emphasis on large river catchments. Similar studies have also been performed across Europe; see for example the papers within special issues of the Hydrological Science Journal (Brázdil and Kundzewicz, 2006) and Hydrology and Earth Systems Science (Kiss et al., 2014).

The 2007 summer floods have increased attention on the impacts of intense rainfall in the UK. A succession of intense rainfall events in 2007 resulted in deaths and widespread flooding affecting 55,000 properties and businesses (EA, 2007; Pitt, 2008), with approximately two-thirds of incidents associated with surface water flooding (Hurford et al., 2012). The Pitt Review of the 2007 floods recognised the benefits to surface water risk assessment of using local knowledge and an understanding of historical flood events to constrain hydraulic modelling (Pitt, 2008). It has also been suggested that historical information can maintain and raise awareness of past events, for example through the creation of physical markers on buildings and sites of historical disasters (Shaw et al., 2005), but it could also be used to provide information on the historical susceptibility of a particular location to flooding.

In the UK there is no organisation responsible for maintaining an archive of flash floods and therefore no ready access to information on the occurrence and severity of past events or to the vulnerability of particular locations. Borga et al. (2011) argue that a comprehensive archive of flash flood events is required to advance analyses of flood climatology, hazard and vulnerability. 
Additionally, the lack of knowledge of flooding in small settlements, often located in ungauged catchments, has been one of the motivations for the compilation of the EA Rapid Response Catchment (RRC) inventory which identifies catchments and settlements that experience a rapid onset of flooding that poses a hazard to people and the presence of vulnerable populations (EA, 2009). A record of the occurrence of intense rainfall events has also been maintained by the UK Meteorological Office (Met Office), which published annual British Rainfall reports from 1863-1968 (Symons British Rainfall from 1863 to 1900). However, since recording gauges are sparse and intense rainfall is often localised, many severe flash floods have occurred (and still occur) without information from accompanying ground-based rainfall gauges. Increasing reliance is being placed on rainfall radar, but its reliability can be impaired in the most extreme events (Sandford et al., 2017).

The SINATRA project (Susceptibility of catchments to INTense RAinfall and flooding), funded by the UK Natural Environment Research Council (NERC), was initiated in 2013 to enhance the understanding of the physical attributes and impacts associated with flooding from high-intensity convective storms. This allowed historical chronologies of flooding from intense rainfall to be compiled for northern and south-west England, using newspaper archives and historical documents dating back to the 1700 s. These chronologies have many potential usages, for example to enable comparisons to be made between recent and historical floods, to judge flood rarity and, from a practical point of view, to assess the adequacy of urban drainage networks (Archer et al., 2017).

This paper presents the newly compiled flood chronologies of past flash flood events, describing:

1. The basis for the inclusion of an event within the database;

2. The documentary materials used in the compilation of the chronologies;

3. The selection of descriptive material for an individual event that is relevant to risk assessment;

4. The associated assessment of rapid rates of rise in water level and discharge;

5. The incorporation of the chronologies into a database;

6. A brief summary of the occurrence of historical flash flood events;

7. An outlook on future uses of the flash flood regional chronologies.

\section{Developing Regional Flash-Flood Chronologies}

Chronologies of flash flood events have been compiled for nine regions, collectively covering northern and south-west England (Table 1 and Figure 1). Each entry in a regional chronology refers to a given date on which one or more intense rainfall events were reported in that region. There are three chronologies for Cumbria, focusing on the River Eden, River Derwent (and Cumbrian coastal rivers) and the South Lakes District (including the Leven and Kent rivers) and also three chronologies for Yorkshire, focusing on the River Swale, the North York Moors (the Esk, Rye and Derwent rivers), and south Yorkshire (the Ure, Nidd, Wharfe, Aire, Calder and Don rivers). The additional three chronologies are for North East England (Northumberland and County Durham), Lancashire and south-sest England (Cornwall and Devon). The rationale for choosing these areas was on the basis of geographical proximity to the authors, given the need to make repeated visits to county offices and libraries, with south-west England being of particular interest as it has experienced several of the most devastating flash floods in Britain (Hand et al., 2004). 
Table 1 The nine flash flood chronology regions and number of database entries

\begin{tabular}{|l|l|}
\hline Region & Number of entries \\
\hline Cumbria, Derwent & 288 \\
\hline Cumbria, Eden & 250 \\
\hline Cumbria, South Lakes District & 468 \\
\hline Lancashire & 557 \\
\hline North East England & 430 \\
\hline South Yorkshire & 622 \\
\hline Swale, Yorkshire & 145 \\
\hline North York Moors, Yorkshire & 195 \\
\hline south-west England & 751 \\
\hline Total & 3,706 \\
\hline
\end{tabular}

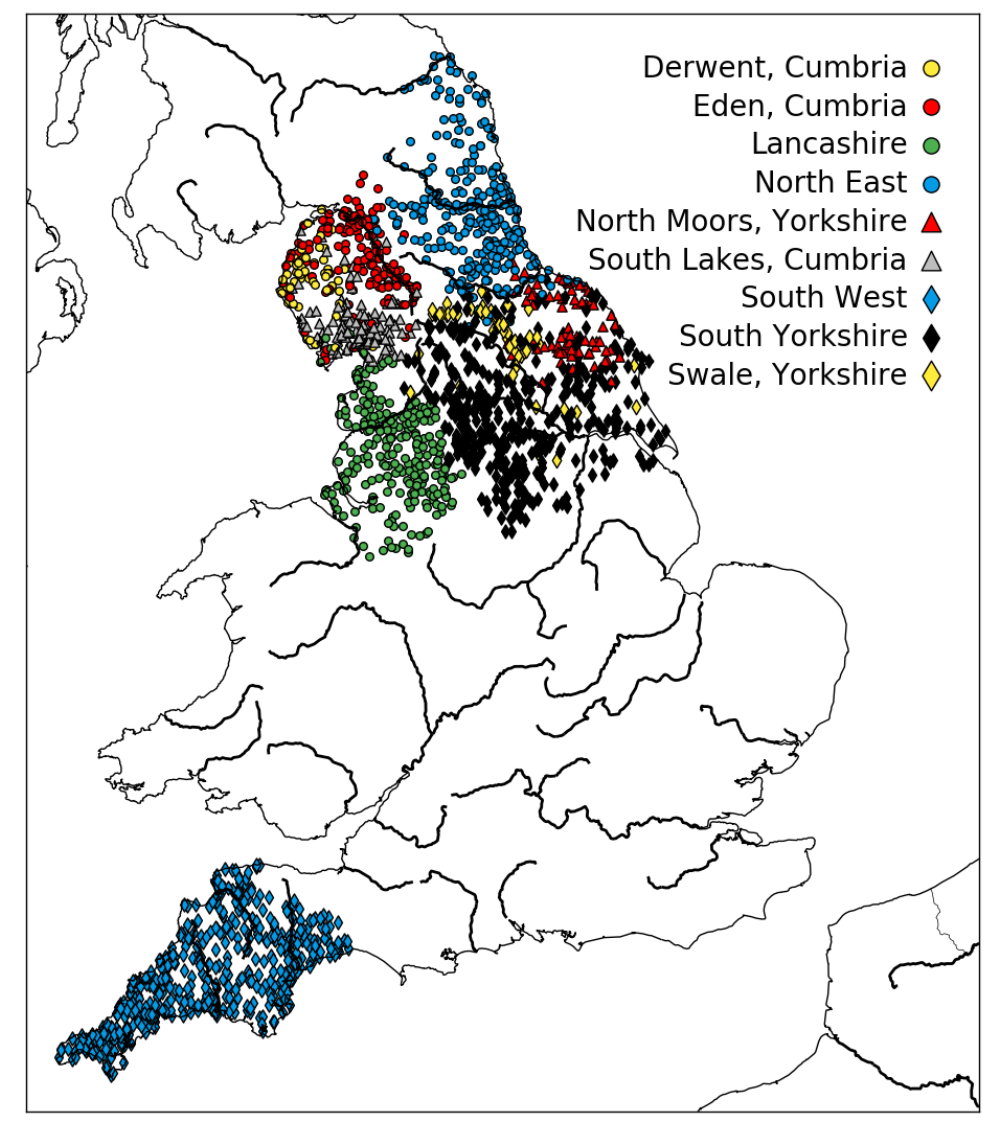

Figure 1 Location of places mentioned in the flood chronologies, separated by region

\subsection{Flash flood characteristics considered for inclusion}

There is no generally accepted definition of a 'flash flood' or a ready means of distinguishing between a flash flood and a slow-rising flood. Implied or explicit definitions of flash floods in other environments do not seem appropriate to British conditions. Individual flash floods in southern Europe have mainly been defined by extreme rainfall totals and peak discharges (e.g. Huet et al., 2003; Lefrou et al., 2000). Gaume et al. (2009), who compiled an inventory of 550 extreme flash floods in seven European countries, suggested that flash floods are generally associated with rainfall exceeding $100 \mathrm{~mm}$ within 24 hours. For conditions in the United States, Georgakakos (1986) suggested a catchment response time of less than 6 hours to define a flash flood, but in Britain this definition would include, what may be considered in many catchments, slow-rising floods. 
Archer and Fowler (2018) provided a definition of the characteristics of British flash floods caused by intense rainfall (i.e. excluding flash floods arising from dam or embankment failure). The speed of onset is considered the most significant feature, with a very short 'threat response time' - defined as the time from the initial perception of a flood to the occurrence of a level posing a threat to life and property. Threat response times are generally $<1 \mathrm{~h}$ but may be virtually instantaneous, and manifested as a 'wall of water' with near instantaneous rise in level of a metre or more (Archer, 1994; Archer and Fowler, 2018). Such events may pose a danger to life, even when the associated peak is not exceptional. Similarly, flash floods (crues rapides) have previously been defined with respect to the speed of onset by Douvinet and Delahaye (2010) on the plateaus of north-western France in a landscape and climate similar to South East England. Flash floods typically occur in small catchments, with areas of a few hundred kilometres or less (Hapuarachchi et al., 2011; Kelsch, 2001), and may also be accompanied by destructive hail and cause severe erosion of hillsides and agricultural land.

Intense rainfall is a necessary, but not sufficient, condition for the initiation of a flash flood (Lóczy et al., 2012). A precise definition of 'intense rainfall' in relation to the initiation of a flash flood is not appropriate as catchment characteristics also need to be taken into consideration; for example, the natural and constructed drainage network, topography and the antecedent conditions. However, the short-duration intensity of rainfall is typically greater than $40 \mathrm{~mm} / \mathrm{hr}$, although in urban areas surface water exceeding drainage capacity often results from higher intensities over much shorter durations (e.g. Phillips, 2003). These intense rainfall events are normally convective and may result from localised individual cells or from mesoscale convective systems, with orography also having an important role in enhancing and concentrating these events (Browning and Hill, 1984; Hand et al., 2004). Given their typically convective origin, events generally occur during the summer months of June, July and August, although events have occurred as late as October or as early as April (Hand et al., 2004).

In compiling the flash flood chronologies, our focus was on the extended-summer period from April to October. As a consequence, winter floods, which provide the majority of annual maximum floods in most British catchments (Black and Werritty, 1997; Mediero et al., 2015) and normally result from persistent rainfall associated with frontal storms and snowmelt, have been excluded (with exceptions). As the boundary between flash floods and slow-onset floods remains imprecise, some events outside the extended-summer period have been retained where the speed of onset or meteorological origin was uncertain.

\subsection{Documentary Sources}

The selection of documentary sources was made on the basis of accessibility, continuity of records and reliability. Exhaustive searches of the monthly Gentleman's Magazine held at the British Library (years accessed: 1731-1800) and continuous runs of regional newspapers stored in the electronic British Newspaper Archive ( 1700 to 1950) were performed. Post-1950 issues of regional newspapers were accessed at local libraries and county record offices. Post-2000 events were primarily identified through internet searches. (The North East, South Yorkshire and Lancashire Chronologies are complete to 2015 and all other the Chronologies to 2013, with the dates reflecting the year of compilation.) During the electronic searches of the Newspaper Archive, the keywords 'flood' and 'thunder' were used to identify events; the term 'flash flood' did not come into usage until the mid-1900s. Additionally, miscellaneous documents including parish registers, ecclesiastical records, Quarter Sessions bridge accounts and academic journals were searched. Several prior compilations of events were consulted, including 'Land of Singing Waters' (Archer, 1992), covering Northumbria, the doctoral thesis of Williams (1957), covering the River Swale in Yorkshire, and the 
British Chronology of Hydrological Events (Black and Law, 2004). It was noted that reports of flooding are often repeated verbatim in multiple newspapers; the source quoted in the Chronologies is the first encountered in the search.

\subsection{Meteorological Information}

The purpose of the chronologies is to document rapid-onset floods, including both surface water and fluvial events. To aid in selecting the dates of identified events for inclusion (and to focus electronic searches), the annual publication, British Rainfall $1863-1968$ was also inspected. These publications provide details of meteorological conditions associated with notable rainfall events and gauge depth-duration totals for 'heavy falls in short periods'. For the period from 1970 to present, we used the Climatological Observers Link (COL; www.colweather.org.uk/) monthly bulletins to provide details of intense rainfall and the associated observers' descriptions of events.

All relevant information was extracted from the documentary sources. This included the location of the flood, the associated meteorological conditions, the occurrence of hail, the magnitude and extent of flooding, the flood depth in buildings, any fatalities from drowning or lightning strikes, any animal losses, details of bridges and buildings damaged by flood or lightning and information on severe channel erosion. Material was included relating to geographical features impacted, thereby providing a basis for comparison with more recent events. Additionally, remarks on the speed of onset of events, especially where this posed a risk to life, are included where available, given this is the principal characteristic of flash floods on the basis of our definition. An example entry is provided in Table 2 .

Table 2 Example of a Flood Chronology entry

\begin{tabular}{|l|l|}
\hline Geographical region & south-west England \\
\hline Date & $1850-05-31$ \\
\hline Description & $\begin{array}{l}\text { Thunderstorm lasting more than 2 hours. Tavistock streets were } \\
\text { flooded; } 1 \text { foot deep in the Post Office. It was a sheet of water in the } \\
\text { cattle market being level with the coping of the wall, erected from the } \\
\text { Guildhall to the Abbey Bridge. A man sitting on the wall was washed } \\
\text { over into the river which was low at the time - he survived. }\end{array}$ \\
\hline Source & North Devon Journal, June $6^{\text {th }}$ \\
\hline Meteorological information & Tavistock 1.3 inches in 1 hour at Tavistock library \\
\hline
\end{tabular}

\subsection{Impact Severity}

An initial classification of the entries based on impact severity has been performed using database searches for keywords. Calianno et al. (2013) provided a methodology to classify and rank the impacts of flash flood severity using contextual comments and information contained within survey data sets. Similarly, Stevens et al. (2016) identified descriptive terms used in the UK Meteorological Office and the UK Centre for Ecology and Hydrology climate summaries to create a classification, recognising the need for supplementary data from newspaper reports. Primarily on the basis of Stevens et al. (2016) the entries have been assigned to 3 classes. The most severe impact entries, Class 3, involve the loss of life and causalities, evacuation and destruction to buildings and infrastructure. Terms selected for Class 2, intermediate impact events, indicate a degree of rarity or high severity. All other events are assigned to Class 1, which are assumed to have localised impacts.

\subsection{Rates of Rise (RoR) Analysis}


The speed of onset of fluvial floods is a key characteristic of flash floods and can be identified in hydrometric records of water level (stage) and discharge in digitised 15-minute interval records. As a separate component of the SINATRA project, a 'rates of rise' (RoR) analysis was carried out to quantify those rates and to assess their probability of occurrence. Analysis was carried out on 2578 flow and stage records provided by the Environment Agency covering the period up to 2013, with 802 stations having at least 20 years of observations. For each record, the moving lag-1, lag-2, lag-4 and lag-8 differences were calculated, resulting in RoR time series based on 15-minute, 30-minute, 1- and 2-hour sampling intervals, respectively.

A Generalised Pareto distribution was then fitted (by maximum likelihood estimation) to threshold exceedances in each RoR series, using the 'fpot' function in the R package 'evd' (Stephenson, 2002). The resulting statistical models were then applied to estimate return periods (expressed in years) of the most extreme such rapid RoR events.

A component of this analysis is incorporated within the Flood Chronologies for south-west England, and is also used within this paper to illustrate an example of rapid RoR for a flash flood on the River Rye in North Yorkshire.

\subsection{Database Compilation}

The Flood Chronologies are available as an SQL database, which has been used to create online interactive web pages. Several additional processing steps have been performed in creating the database. Firstly, place names mentioned in the event descriptions were identified using the Ordnance Survey 'Open Names' GIS data layer, which provides the locations of 44,000 settlements within Britain. Given that place names are often not unique, the geographical extent of the data layer was restricted during identification, typically to the county[s] to which the particular chronology applied. Further manual inspection was performed to remove any incorrect matches that may have arisen, for example, due to a place name forming part of a street or road name. Secondly, additional data from a national set of daily rainfall gauges was obtained for the identified flood events for use in the creation of interactive maps, thus providing an indication of the associated rainfall event's spatial extent and intensity. For 1863-1968, the 'heavy falls on rainfall days' data in the British Rainfall publications have also been included within the database. These data have previously been extracted from digital copies (MacDougall, 2010), but the locations of the gauges are not provided. Gauge locations were obtained from the Met Office archives and later copies of British Rainfall (from the 1960s), within which locations are provided. Blenkinsop et al. (2017) provide a national data set of quality-controlled tipping bucket rainfall gauge data at a $1 \mathrm{hr}$ time resolution. For consistency with British Rainfall, these data have been aggregated to daily totals (9am-9am) and incorporated into the database. However, few gauges are available prior to 1990. A future update of the interactive web pages will extend the rainfall data content to include this newly-quality-controlled $1 \mathrm{hr}$ rainfall gauge data and a $1 \mathrm{hr} 1 \mathrm{~km}$ gridded dataset across the UK (Blenkinsop et al., 2017; Lewis et al. submitted).

The interactive web pages derived from the chronologies comprise: (1) the entries searchable by keywords and (2) interactive maps, showing rainfall, and searchable by place. These are publicly accessible at http://ceg-fepsys.ncl.ac.uk/fc. Each of the nine chronologies is provided on an individual webpage. Figure 2 shows an interactive map for an entry from the south-west Chronology for Ottery St Mary (2008), providing daily rainfall totals and the descriptive text. 


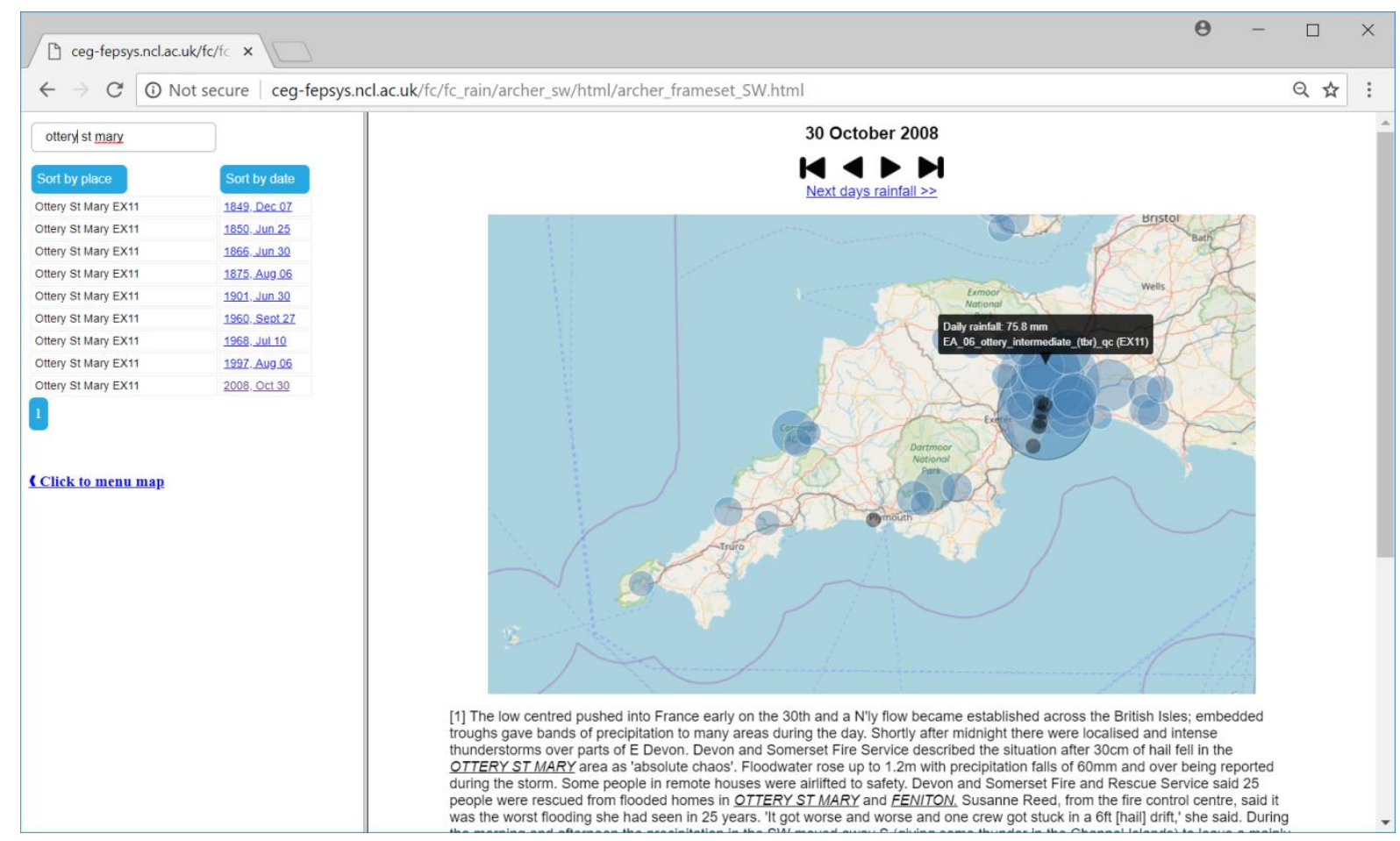

Figure 2 Example entry from the south-west Chronology showing daily rainfall totals (blue circles) in the vicinity of Ottery St Mary, October 2008.

The spatial extent of the flood chronologies is provided in Figure 1. Each marker depicted on the map shows the location of a place identified in a flood event description. A total of 1836 places are mentioned, of which 347 are classified as hamlets in the Open Names data layer, 1034 as villages, 351 as towns, 20 as cities, 16 as suburban areas and 68 are unclassified urban areas. It is noted that 202 places mentioned in the chronologies are also included in the EA Rapid Response Catchment (RRC) inventory (which has a total of 393 places in England and Wales), 201 of which are assigned the classification 'very extreme hazard'.

\section{Results}

\subsection{Regional time series of events}

Figure 3 shows, for each chronology, the number of entries provided for each decade, 1700 to 2000, inclusive (there are only a small number of entries prior to 1700). Taking into consideration the decadal variability, prior to 1850 there are typically fewer entries which may reflect the lack of establishment of regional newspapers, which increase in number over the 1800 s. Additionally, there have been changes in exposure over time, as a result of increasing populations and numbers of dwellings, and construction of flood defence measures.

The temporal clustering of flood events within the UK, into flood-rich and flood-poor periods, has previous been analysed, primarily using river flow records. During the instrumental period there was a flood-poor period in the 1970s and a flood-rich period post-2000 (Hannaford and Marsh, 2008). Macdonald and Sangster (2017) constructed historical flood chronologies for 12 British catchments, from 1750-present, using instrumental river flow data and historical water levels derived from documented descriptions. They identified the 1850s, 1875-1885, late-1940s, mid-1960s and 2000present as flood-rich periods.

Although the focus here is on summer flash floods, there is a degree of correspondence between the frequency of flash-flood entries per decade and previously identified flood-rich periods in Figure 3 
(black bars indicate the previously identified flood-rich periods). The correspondence is strongest for the River Eden, Lancashire and the North East, for which at least three of the decades with the highest number of entries correspond to a flood-rich period. However, Macdonald and Sangster (2017) did note regional variations in the timings of flood-rich periods and the chronologies presented here include surface water floods and fluvial floods in headwater catchments that may not have previously been identified. This means that care should be taken in the interpretation of the temporal variability of entries, given that each is weighted equally but some entries are associated with large and widespread impacts. 

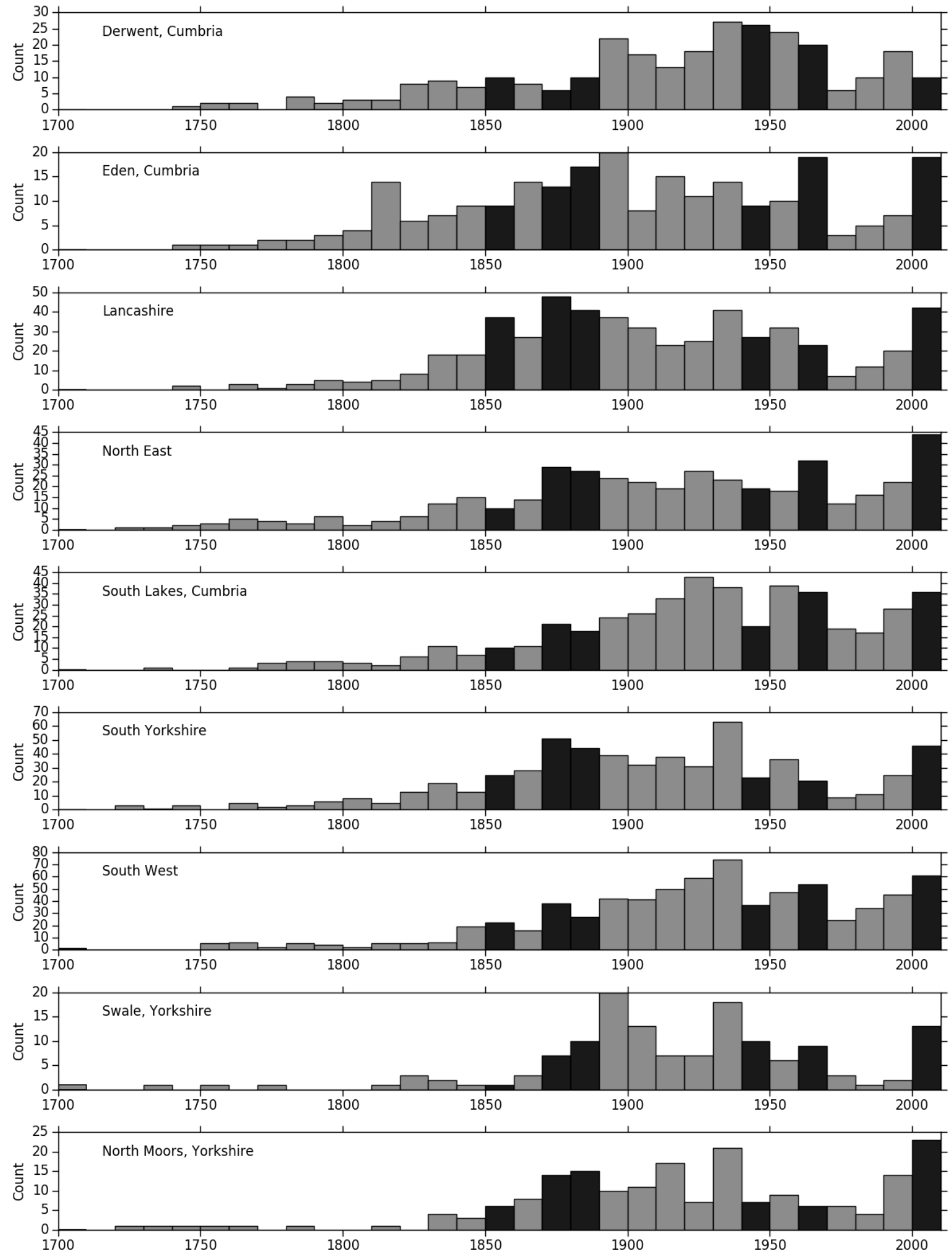

Figure 3 Number of entries per decade in each regional chronology. Black bars indicate previously identified flood-rich periods. 


\subsection{Contrasting North East and south-west England}

Here we explore the two most detailed chronologies, for south-west England and North East England, in greater detail. For south-west England, digital archives were available for seven local newspapers (combined coverage from 1800-1950), and visits were made to the county record offices of Cornwall and Devon where cuttings from local newspapers were available for 1950-2007. Archer (1992) provides a detailed account of flooding in Northumbria, which was supplemented by newspaper archives maintained by Newcastle City Library, where cuttings for the categories of climate and flooding have been separately maintained.

The seasonality of the entries in the regional chronologies is provided in Figure 4, with the colour coding of the stacked bars indicating the number of events in each of three categories of impact severity (where Class 3 is the most severe). The monthly distribution of events is consistent with the seasonality of UK hourly extreme rainfall (Blenkinsop et al., 2017; Hand et al., 2004). The percentage of events in the summer period (June-August) is 63\% and 50\% for North East England and southwest England, respectively.
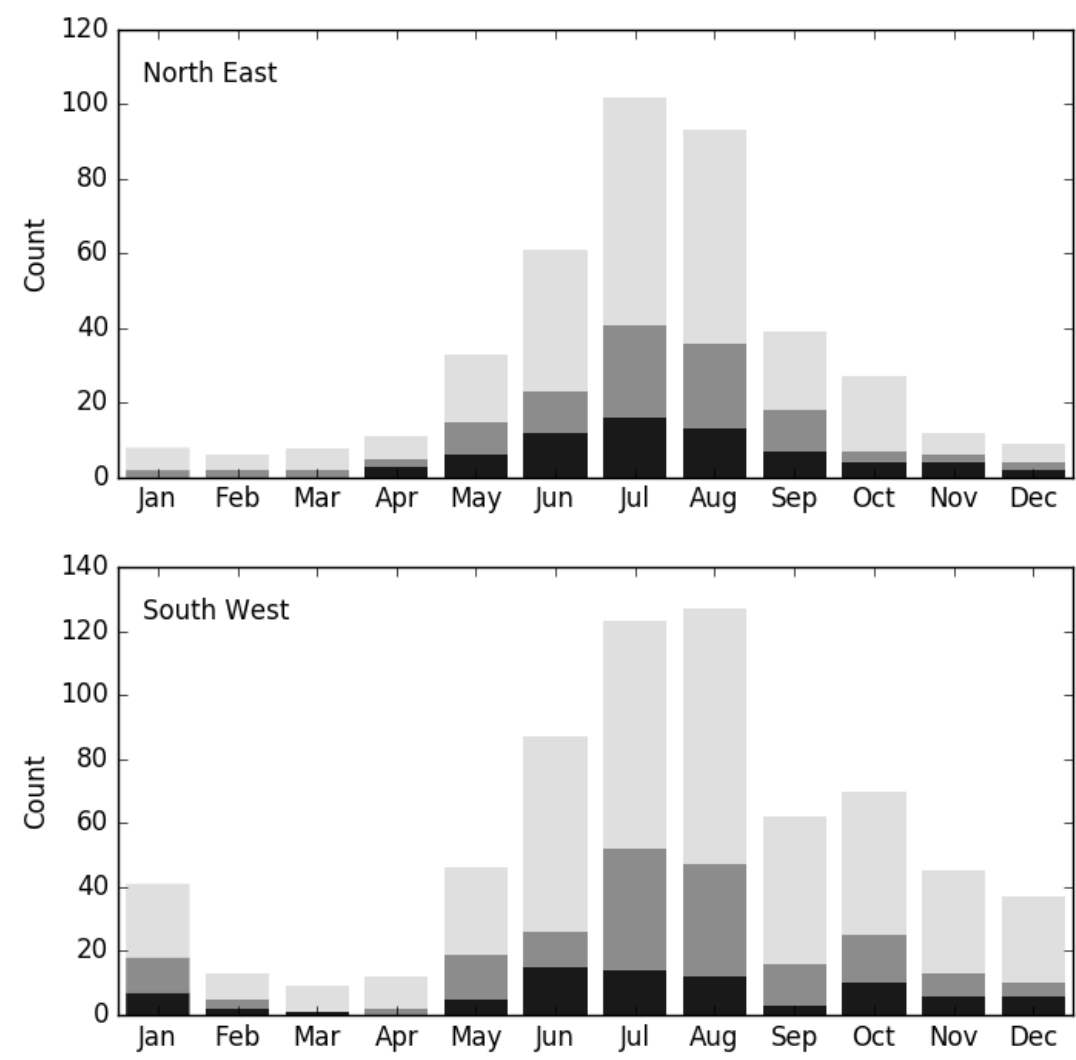

Figure 4 Number of entries for the North East England and south-west England regional chronologies, with impact severity classifications indicated (black: Class 3, dark grey: Class 2; light grey: Class 1).

The frequency of some different terms used in the flood descriptions within the North East England and south-west England regional chronologies are provided in Table 3. Despite the different source material used to compile the two chronologies, the frequency of terms used is similar (when noting the different number of entries in each region). It should be noted that in some cases a fatality may refer to livestock, for example: "A cart and horses was washed away in crossing a normally very small stream; the horses were drowned and the occupants rescued with difficulty." (June $21^{\text {st }}, 1828$, Exeter and Plymouth Gazette). Given that this event posed a threat to life, it was retained in Class 3. 
We have assigned each entry to a single impact severity class based on the highest ranking term contained within the text description. Particularly in North East England, there are few high magnitude events in the winter (December to March) and spring periods (April-May) (see Figure 4). This, in part, reflects the methodology for event selection, in addition to the dangers posed by flash floods.

Table 3 Frequency of terms used in North East NE and south-west SW Chronologies

\begin{tabular}{|c|c|c|c|}
\hline Term & NE & SW & Class \\
\hline death & 5 & 8 & \multirow{7}{*}{ 3. High impact } \\
\hline drowned & 29 & 34 & \\
\hline disastrous & 0 & 4 & \\
\hline destructive & 5 & 4 & \\
\hline destroyed & 19 & 38 & \\
\hline devastation & 0 & 6 & \\
\hline evacuated & 12 & 2 & \\
\hline notable & 1 & 5 & \multirow{10}{*}{ 2. Intermediate impact } \\
\hline major & 4 & 17 & \\
\hline unprecedented & 4 & 6 & \\
\hline significant & 2 & 3 & \\
\hline substantial & 0 & 3 & \\
\hline severe & 67 & 95 & \\
\hline widespread & 25 & 42 & \\
\hline serious & 35 & 39 & \\
\hline extensive & 12 & 12 & \\
\hline considerable & 24 & 25 & \\
\hline localised & 8 & 15 & 1. Low impact \\
\hline
\end{tabular}

The number of entries per year is provided in Figure 5, colour coded by the impact severity classification. The 10-year moving average of the entries for both regional chronologies shows peak frequencies centred on about 1880,1900,1930, 1965 and the late 2000s. Stevens et al. (2016) also noted a high incidence of reported floods between 1910 and the mid-1930s, a low incidence until the 1960 s, followed by a gradual increase. This may possibly be linked to long-term variability in large scale drivers such as the North Atlantic Oscillation and/or the Atlantic Meridional Overturning Circulation (Kendon et al., 2018). 

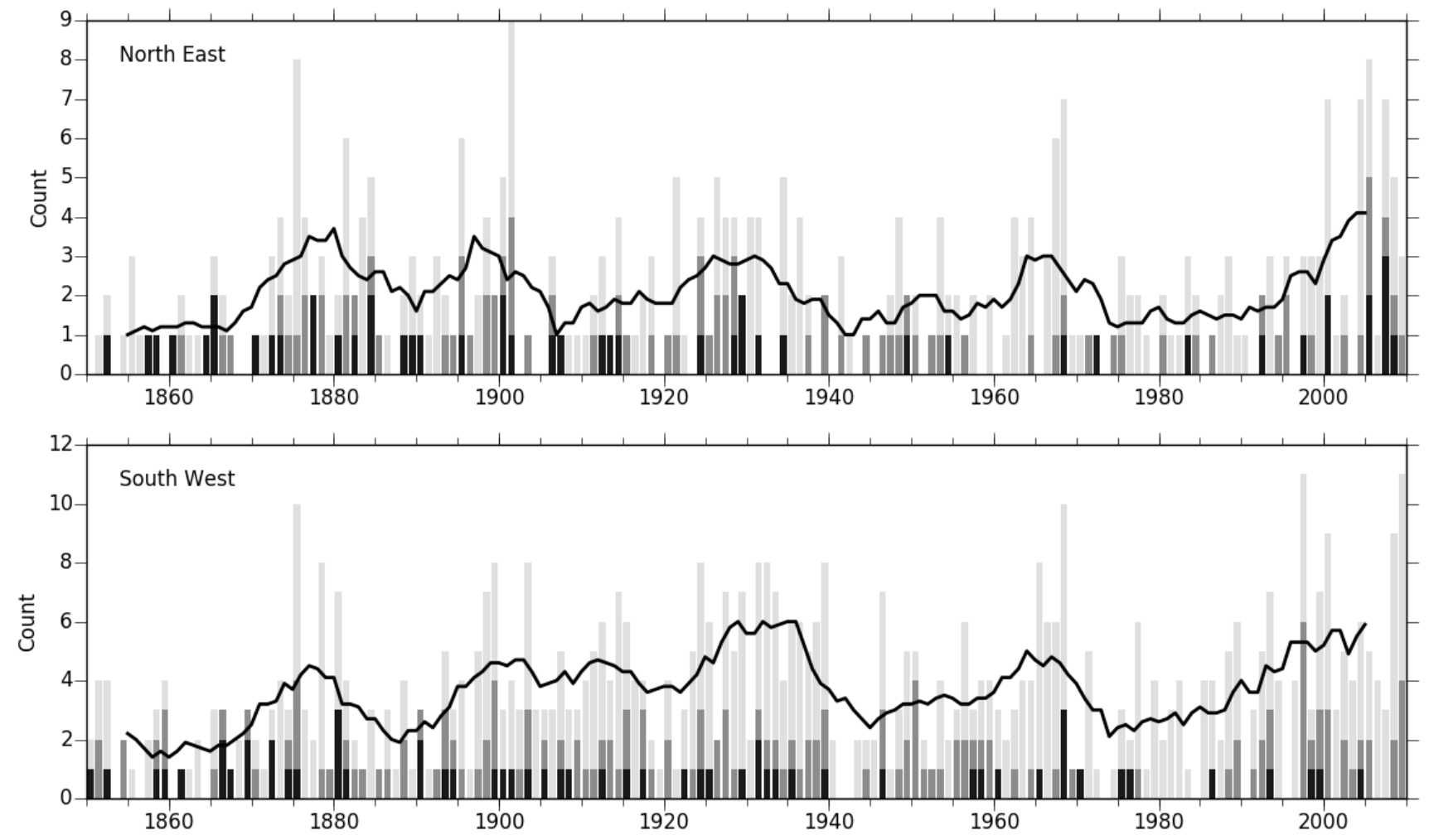

Figure 5 Number of entries per year, 1850-2010 (black line: 10 year running mean; Class 1, 2 and 3 events in light grey, dark grey and black, respectively)

\subsection{Illustrative Examples}

Three examples are briefly described here to indicate how the chronology might be used to assess both catchment/location susceptibility and catchment response to flash floods. The first example provides information regarding the history of flooding prior to the flood experience of resident, the second demonstrates how recent floods can be placed in the context of the pre-instrumental record, and the third provides information on rapid response in ungauged catchments.

\section{North Yorkshire Wolds}

The Yorkshire Wolds are a chalk outcrop in North East England, characterised by a low drainage density network and seasonal streams. Despite the permeability of the chalk, there is a history of flash flooding from convective rainfall events. For example, Clark (2007) reported a number of thunderstorms $(1657,1888,1892$ and 1910) in a usually dry valley that caused flash floods which inundated the downstream village of Langtoft.

The reporting of a severe flash flood in May 1800 in the Thixendale valley, $18 \mathrm{~km}$ to the west of Langtoft, places this flood risk into a different perspective, that of a 'rapid response catchment'. The following account of the Thixendale flood taken from the North East chronology is drawn from several newspapers:

"Soon after the storm abated the houses were suddenly inundated by a large body of water which came down the valley like a large wave and in a few minutes almost every house had three feet of water in it. Inhabitants were obliged to take to their chambers or to the hillsides. One child in a cradle which filled with water was saved by a girl who broke a window into the house to rescue the child. The houses were all left with 4 inches of mud in them. In its descent from the summit of the hill the flood left two holes in the rock nearly six feet deep. The flood continued its course to 
Raisthorp and Birdsall, a large body 30 yards broad taking with it all the hedges and fences. At nearby Leavening and Acklam numbers of sheep were washed away and drowned and the posts and rails of an enclosure together with the banks were carried for some distance."

Further analysis of the North East chronology provides evidence that flash flooding is a common phenomenon in the Yorkshire Wolds, although the majority of reported events were prior to 1950 (Figure 5). Following the summer 2007 floods, which affected much of England including the Wolds, several reports highlighted a lack of local flood knowledge (Haughton et al., 2015). In response, the East Riding of Yorkshire Council compiled a record of historic flood events to gain additional knowledge of how and where flooding may occur (ERYC, 2011), although it is noted that the inventory is not as comprehensive as chronology presented here.

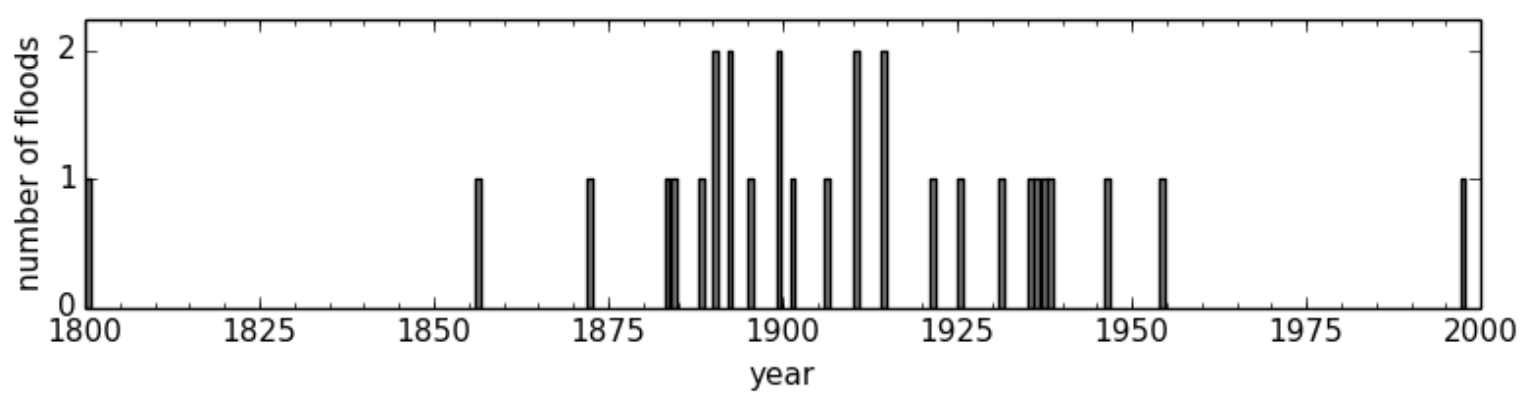

Figure 6 Floods reported in the Yorkshire Wolds from the North East Chronology.

\section{Helmsley and River Rye, North York Moors}

The catastrophic floods that hit Helmsley on 19 June 2005 were widely reported on national television and in the press (Cinderey, 2005). Parts of Helmsley and neighbouring villages, particularly Hawnby, were devastated, with many houses flooded, some being structurally damaged. Cars and caravans were swept away by the swollen streams; one car being found $8 \mathrm{~km}$ from where it had been parked. No human lives were lost but many animals were drowned. Wass et al. (2008) estimated the rainfall return period in the Upper Rye catchment at 400 years, but the flow return period at over 10,000 years. An estimate of $400 \mathrm{~m}^{3} / \mathrm{s}$ peak discharge, based on reconstructions of the peak flow for the River Rye at Broadway Foot using modelling and wrack mark (maximum water level) data, was 11 times QMED (the median annual flood flow). The extreme conditions appeared to deserve the description of 'unprecedented' and there had been no floods to approach the magnitude of the 2005 event within living memory. However, our historical evidence shows that an equal or more severe flood occurred in Helmsley in October 1754:

The Universal Magazine (1754, p. 235) notes: "A sudden inundation of the river Rye happened at Helmsley in Yorkshire, such as had never been known by the oldest people in those parts, probably occasioned by the late heavy rains. Two houses were entirely washed away, the one inhabited by James Holdforth, he and his whole family drowned, except his wife, who being sick in her bed, was carried down the stream half a mile, and at last washed off into a field, where she was found the next morning very little hurt. The other house belonged to John Sunley, was also drowned, and all his family. In the whole thirteen persons". John Pape's diary noted that eight houses were driven to the ground. There were no accompanying accounts of rainfall intensity, but the flood was far more widespread than the 2005 flood, with bridges destroyed or damaged north and south of the North York Moors. From this we may infer that the event was larger than that in 2005. 
Bringing historical evidence into estimation of return periods (with two similarly extreme events in 250 years) provides a different perspective on flood risk, in comparison with the return periods of the 2005 flood as estimated by conventional methods (i.e. based on peak river flows or levels). At Broadway Foot, some $2 \mathrm{~km}$ downstream of Hawnby, river gauge records are available from the mid1970s. During the June 2005 flood, the river gauge recorded increases in water level of $1.43 \mathrm{~m}$ over 15 minutes, $2.39 \mathrm{~m}$ over 30 minutes and $3.4 \mathrm{~m}$ over one hour (these data were recorded on the rising limb of the flood hydrograph, just before the gauge was damaged by the flood). These exceptional RoR in June 2005 are clearly visible in the context of the longer instrumental record in Figure 7(a), although there have been several other relatively extreme, but smaller, events in recent history. Figure $7(b)$ shows that the most extreme RoR events in the instrumental record have occurred in summer months.
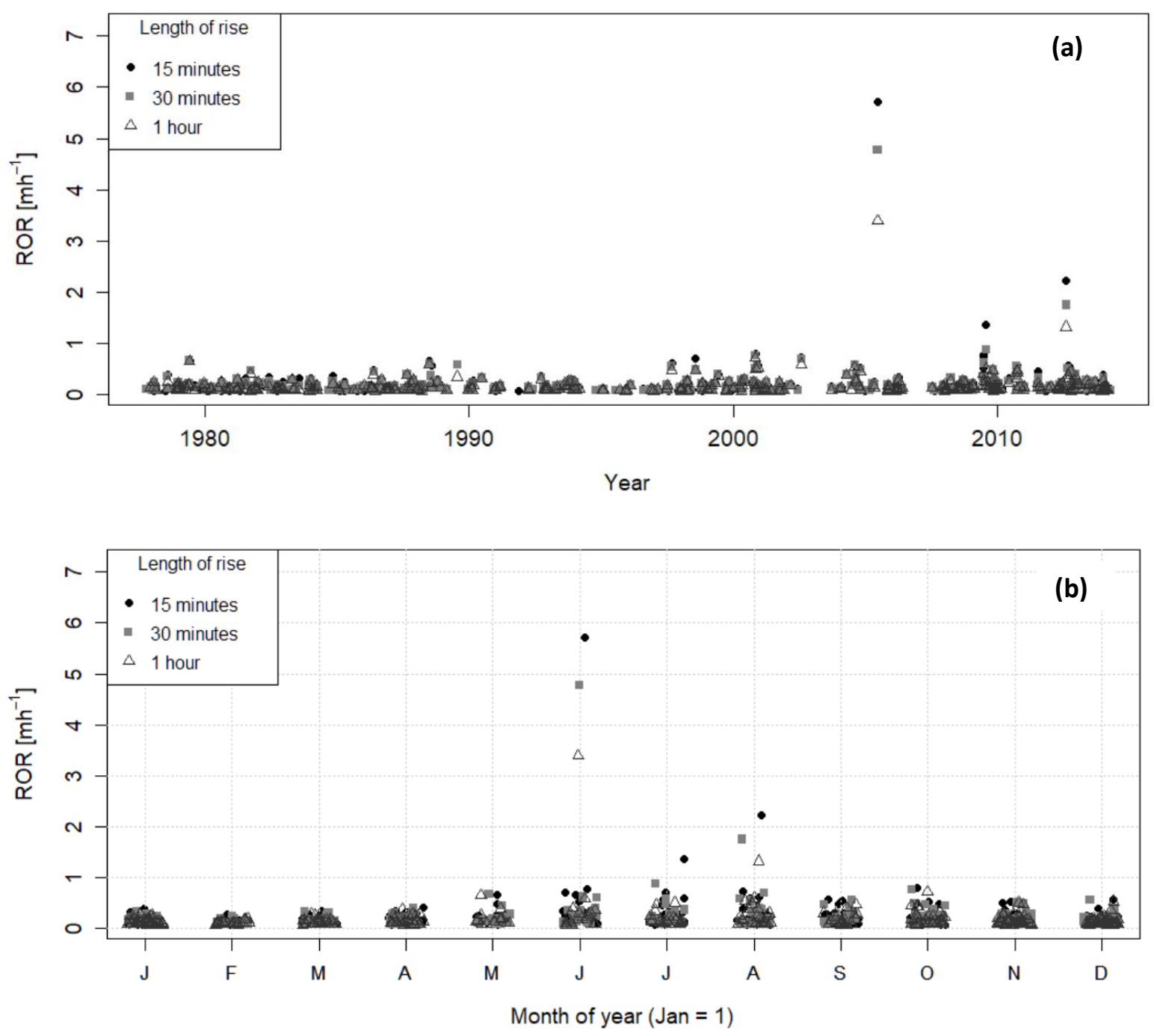

Figure 7 Rates of rise (ROR) in water levels at Broadway Foot river gauge, expressed on a common scale in metres per hour for sampling durations of 15 minutes, 30 minutes and 1 hour: (a) Historical time series; (b) Seasonality (data points jittered within each month for visual effect, to avoid over-plotting).

Calculating return period estimates using the instrumental data gives ca. 880 years, 431 years and 561 years for RoR in water level over 15-minute, 30-minute and one-hour durations, respectively, as shown in Figure $8(a-c)$. These analytical results are consistent with an interpretation of the historical 
documentary evidence that suggests RoR in water level may be far more likely than the $<1 / 10,000$ annual exceedance probability (i.e. $>10,000$ year return period) ascribed to the peak flow rate in June 2005 by Wass et al. (2008).

(a) 15 minutes

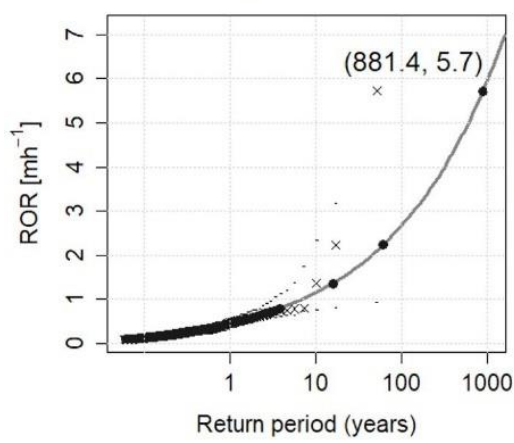

(b) 30 minutes

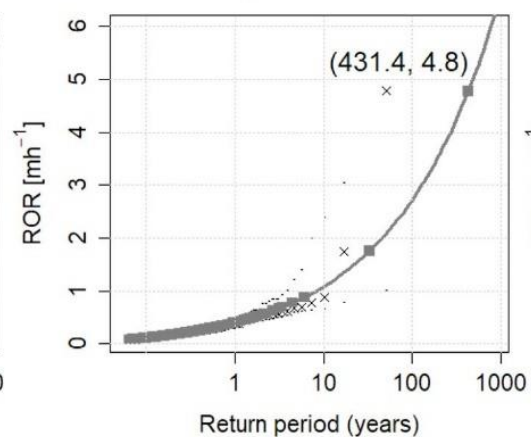

(c) 1 hour

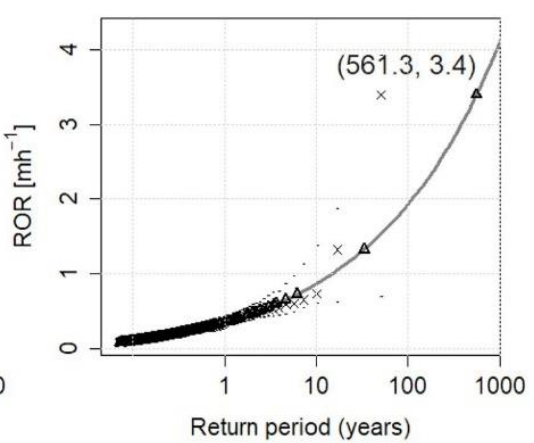

Figure 8 Statistical analysis of extreme rates of rise (RoR) for water levels at Broadway Foot river gauge. Peak RoR (rescaled to the hourly equivalent rates) are plotted against return period, estimated with generalised Pareto distribution models (solid curves) fitted to the ROR extreme observations (symbols, matching Figure 6). Short dashes indicate 95\% confidence intervals. Also plotted are rank-based plotting position estimates of the return period of the observed extremes (' $x$ ' symbols). The numbers in parentheses are the estimated return period and ROR of the June 2005 event.

\section{Braunton and the River Caen North Devon}

Recent and historical floods have affected the town of Braunton on the ungauged River Caen which flows into the estuary of the River Taw in north Devon. Flooding of property from inadequate drainage of surface runoff has been most frequent, but serious winter floods from the overtopping of the River Caen have occurred on several occasions. A recent winter storm on 26 November 2016 caused flooding in South Street, Caen Street, Challoners Road, Station Road and Velator Road, whilst serious flooding also occurred in December 2012 and December 2004. However, perhaps the most severe event experienced in Braunton was a summer flood on 5 June 1931 caused by intense rainfall in the headwaters of the River Caen. British Rainfall notes a daily rainfall of 2.31 inches $(59 \mathrm{~mm})$ measured at 09.00 on 5 June mostly fell in a 1.5 hour period from 06.30 to 08.00 . The flood water reached Braunton at about 09.30. The Chronology of British Hydrological Events (CBHE) also describes this event but omits some of the following details on the hazards of rapid onset. Reports from the North Devon Journal and the North Devon Herald are summarised below:

Spreacombe: "'The trouble arose from a cloudburst on Roddaway. We had no warning whatever of the approach of the flood; before we knew where we were the raging torrent swept down upon us flooding everything in its path. My workmen and I could do nothing but run for our lives." To escape the farmer jumped on a large corn chest but within a few seconds it was floating around in the barn; he then scrambled for a high oak beam and made his way to the stable adjoining. Two cows ready for milking were swept away. Horses were up to their necks.

Braunton: At one stage the Caen was already high when inhabitants were amazed to see a small bore nearly a foot high surging down the New Challoners Road. The rapid rise did not allow for remedial response and practically every building in the vicinity was flooded. The Square was entirely 
inundated and at the other end of the Main Street the water poured over the railway crossing carrying outbuildings. It poured down South Street like a stream. An observer noted: "The water came from Heddon Mill like a tidal river, the streams having burst their banks were restrained in their progress by bridges over which the muddy torrent mounted". In Caen Street the water was 5 feet deep.

Such a summer flood has, in addition to the flood peak, the added hazards of the short lag time between the occurrence of rainfall and the onset of flooding and then a rapid or near instantaneous RoR. Flood warning and response must be tailored to these added hazards. This historical information is able to provide information on flow response in this ungauged catchment, helping to define it as a rapid response catchment.

\section{Discussion and Conclusions}

The flash flood chronologies provide a unique time series of flood events arising from intense rainfall. These complement the Chronology of British Hydrological Events (CBHE) by focussing on rapid onset flood events (including consequent risk to life), associated meteorological hazards of lightning and hail, and morphological impacts, which may in some cases be linked with information about flood depths or extents. The methodology and compilation of nine flood chronologies has been described, which collectively comprise a total of 3,706 entries, dating from the 1700 s. This long data set provides a wealth of information on historical events, opening a number of avenues for future research.

The chronologies provide valuable insights for flood risk assessment and management. For improving flood risk assessments for peak discharges in rivers, the effective use of historical and local data can be expected to lead to more effective spending on flash flood risk management (EA, 2017). In the case of surface water flooding, design of sewer systems or Sustainable drainage systems (SuDs) can be better targeted. Frequency analysis may further underline the importance of not overlooking risks stemming from extremely rapid rises in water levels, which could in some cases provide a more likely, or impactful, hazard than the associated peak river flow, as in one of the examples explored here. To aid flood practitioners, it would be useful to further combine the chronologies with quantitative data relating to catchment characteristics and geomorphology for the identification of high risk settlements. For example, this could be used to extend the Rapid Response Catchment inventory (EA, 2009). Given that intense summer rainfall events are projected to become more frequent in the future (Kendon et al., 2014), many places that have not previously experienced flash flooding may become vulnerable, and places that have flooded historically may suffer exposure to more frequent, and larger, events. Much of the information contained within the chronologies will also be useful in flood event reconstruction, such as information on the extent of flooding (streets and land marks impacted) to estimate past discharges and levels. These are critical for the design of flood alleviation measures.

The use of historical flood records, flash floods or otherwise, to assess future impacts depends to some extent on the long-term stationarity of climate. The stationarity assumption in flood risk management has been challenged by the magnitude of current hydroclimatic change with global warming. Milly et al. (2008) argued that stationarity should no longer serve as a central default assumption, however, there have been dissenting voices (Lins and Cohn, 2011; Matalas, 2012). Villarini et al. (2009) note that it may be easier to claim non-stationarity than to prove it through analysis of actual data. Indeed, historical databases highlight natural climatic variability affecting the 
frequency or magnitude of flash floods. For example, Archer et al. (2017) on the basis of these Chronologies drew up a decadal time series of the occurrence of flash floods in North East and south-west England suggesting a greater decadal frequency during the late nineteenth and early twentieth centuries than during the last 60 years of more readily available observations which are typically used for future impact assessments.

Relevance for assessing future risks also depends on effects of changes in catchment or channel conditions especially for surface water flooding in urban areas. Changes in the urban surface permeability (likely to increase flood risk) and improvements to subsurface drainage (likely to decrease flood risk) may have altered the risks at given locations. However, in extreme events where the rainfall intensity is far in excess of the design capacity of both current and historical drainage systems, surcharging of sewers and surface flows exceeding gulley capacity may lead to ponding of surface water at the same critical points in spite of urban expansion. Archer et al, (2017) describe an example in Newcastle upon Tyne North East England, where the same location was flooded at intervals by intense rainfall from 1833 to the most recent incident in 2012 .

Additional analysis of the database is needed to provide greater insight regarding the meteorological conditions and the impacts associated with flash flood events. This may complement ongoing attempts to link occurrences of high intensity rainfall with synoptic weather patterns and teleconnections for the understanding of long-term trends in flood frequency (e.g. Jacobeit et al., 2003).

So far, regional chronologies have been compiled only for northern and south-west England. The extraction of data is time consuming but, given the unique value of the database, it is recommended that the analysis be extended to cover the whole of the United Kingdom, accompanied by wider (and periodically updated) quantification of RoR from gauged data.

\section{Acknowledgments}

This research formed part of the SINATRA project which is supported by the United Kingdom NERC Flooding From Intense Rainfall programme (grant NE/K00896X/1). Hayley Fowler is funded by the Wolfson Foundation and the Royal Society as a Royal Society Wolfson Research Merit Award (WM140025) holder.

\section{References}

Archer, D., 1992. Land of Singing Waters: Rivers and Great Floods of Northumbria Spreddon Press, Stocksfield, UK.

Archer, D.R., Fowler, H.J., 2018. Characterising flash flood response to intense rainfall and impacts using historical information and gauged data in Britain. Journal of Flood Risk Management: 11 (51), 5121-5133

Archer, D.R., Parkin, G., Fowler, H.J., 2017. Assessing long term flash flooding frequency using historical information. Hydrology Research, 48(1): 1-16

Bayliss, A., Reed, D., 2001. The use of historical data in flood frequency estimation. Report to Ministry of Agriculture, Fisheries and Food, Centre for Ecology and Hydrology, Wallingford, UK.

Benito, G. et al., 2004. Use of Systematic, Palaeoflood and Historical Data for the Improvement of Flood Risk Estimation. Review of Scientific Methods. Natural Hazards, 31(3): 623-643. DOI:10.1023/B:NHAZ.0000024895.48463.eb 
Black, A.R., Law, F.M., 2004. Development and utilization of a national web-based chronology of hydrological events. Hydrological Sciences Journal, 49(2): 237-246. DOI:10.1623/hysj.49.2.237.34835

Black, A.R., Werritty, A., 1997. Seasonality of flooding: a case study of North Britain. Journal of Hydrology, 195(1): 1-25. DOI:https://doi.org/10.1016/S0022-1694(96)03264-7

Blenkinsop, S., Lewis, E., Chan, S.C., Fowler, H.J., 2017. Quality-control of an hourly rainfall dataset and climatology of extremes for the UK. International Journal of Climatology, 37(2): 722-740. DOI:10.1002/joc. 4735

Borga, M., Anagnostou, E.N., Blöschl, G., Creutin, J.D., 2011. Flash flood forecasting, warning and risk management: the HYDRATE project. Environmental Science \& Policy, 14(7): 834-844. DOI:https://doi.org/10.1016/j.envsci.2011.05.017

Brázdil, R., Kundzewicz, Z.W., 2006. Historical hydrology-Editorial. Hydrological Sciences Journal, 51(5): 733-738. DOI:10.1623/hysj.51.5.733

Brázdil, R., Kundzewicz, Z.W., Benito, G., 2006. Historical hydrology for studying flood risk in Europe. Hydrological Sciences Journal, 51(5): 739-764. DOI:10.1623/hysj.51.5.739

Browning, K.A., Hill, F.F., 1984. Structure and evolution of a mesoscale convective system near the British Isles. Quarterly Journal of the Royal Meteorological Society, 110(466): 897-913. DOI:10.1002/qj.49711046607

Calianno, M., Ruin, I., Gourley, J.J., 2013. Supplementing flash flood reports with impact classifications. Journal of Hydrology, 477(Supplement C): 1-16. DOI:https://doi.org/10.1016/j.jhydrol.2012.09.036

Cinderey, M., 2005. North York Moors storms -19 June 2005. Weather, 60(9): 273-273. DOI:10.1256/wea.155.05

Clark, C., 2007. Flood risk assessment using hydrometeorology and historic flood events. International Water Power \& Dam Construction, 59(4): 22-30.

Douvinet, J., Delahaye, D., 2010. Caractéristiques des «crues rapides» du nord de la France (Bassin parisien) et risques associés. Géomorphologie: relief, processus, environnement, 16(1): 7390.

EA, 2007. Review of 2007 summer floods, Environment Agency, Bristol, UK.

EA, 2009. Understanding of and response to severe flash flooding, Science Report: SC070021 Environment Agency, Bristol.

EA, 2017. Making better use of local data in flood frequency estimation, Environment Agency, Bristol, UK.

ERYC, 2011. Preliminary flood risk assessment, East Riding of Yorkshire Council.

Gaume, E. et al., 2009. A compilation of data on European flash floods. Journal of Hydrology, 367(1): 70-78. DOI:http://dx.doi.org/10.1016/i.jhydrol.2008.12.028

Georgakakos, K.P., 1986. On the Design of National, Real-Time Warning Systems with Capability for Site-Specific, Flash-Flood Forecasts. Bulletin of the American Meteorological Society, 67(10): 1233-1239. DOI:10.1175/1520-0477(1986)067<1233:OTDONR>2.0.CO;2

Hall, J. et al., 2015. A European Flood Database: facilitating comprehensive flood research beyond administrative boundaries. Proceedings of the International Association of Hydrological Sciences, 370: 89-95.

Hand, W.H., Fox, N.I., Collier, C.G., 2004. A study of twentieth-century extreme rainfall events in the United Kingdom with implications for forecasting. Meteorological Applications, 11(1): 15-31. DOI:10.1017/S1350482703001117

Hannaford, J., Marsh, T.J., 2008. High-flow and flood trends in a network of undisturbed catchments in the UK. International Journal of Climatology, 28(10): 1325-1338. DOI:10.1002/joc.1643

Hapuarachchi, H.A.P., Wang, Q.J., Pagano, T.C., 2011. A review of advances in flash flood forecasting. Hydrological Processes, 25(18): 2771-2784. DOI:10.1002/hyp.8040 
Haughton, G., Bankoff, G., J Coulthard, T., 2015. In search of 'lost' knowledge and outsourced expertise in flood risk management. Transactions of the Institute of British Geographers, 40(3): 375-386. DOI:10.1111/tran.12082

Huet, P. et al., 2003. Retour d'expérience des crues de septembre 2002 dans les départements du Gard, de l'Hérault, du Vaucluse, des Bouches-du-Rhône, de l'Ardèche et de la Drôme. Rapport de l'Inspection Générale de l'Environnement, Ministere de l'écologie et du développement durable.

Hurford, A.P., Priest, S.J., Parker, D.J., Lumbroso, D.M., 2012. The effectiveness of extreme rainfall alerts in predicting surface water flooding in England and Wales. International Journal of Climatology, 32(11): 1768-1774. DOI:10.1002/joc.2391

Jacobeit, J., Glaser, R., Luterbacher, J., Wanner, H., 2003. Links between flood events in central Europe since AD 1500 and large-scale atmospheric circulation modes. Geophysical Research Letters, 30(4): 1-4. DOI:doi:10.1029/2002GL016433

Kelsch, M., 2001. Hydrometeorological Characteristics of Flash Floods. In: Gruntfest, E., Handmer, J. (Eds.), Coping With Flash Floods. Springer Netherlands, Dordrecht, pp. 181-193. DOI:10.1007/978-94-010-0918-8_18

Kendon, E.J., Blenkinsop, S., Fowler, H.J., 2018. When Will We Detect Changes in Short-Duration Precipitation Extremes? Journal of Climate, 31(7): 2945-2964. DOI:10.1175/jcli-d-17-0435.1

Kendon, E.J. et al., 2014. Heavier summer downpours with climate change revealed by weather forecast resolution model. Nature Climate Change, 4: 570-576.

Kiss, A., Brázdil, R., Blöschl, G. (Eds.), 2014. Hydrol. Earth Syst. Sci. Special Issue, Floods and their changes in historical times - a European perspective, 19.

Leese, M.N., 1973. Use of censored data in the estimation of Gumbel distribution parameters for annual maximum flood series. Water Resources Research, 9(6): 1534-1542. DOI:10.1029/WR009i006p01534

Lefrou, C. et al., 2000. Les crues des 12, 13 et 14 novembre 1999 dans les départements de l'Aude, de l'Hérault, des Pyrénées-Orientales et du Tarn. Inspection Générale de l'Environnement Rep. 00/004.

Lins, H.F., Cohn, T.A., 2011. Stationarity: Wanted Dead or Alive? JAWRA Journal of the American Water Resources Association, 47(3): 475-480. DOI:doi:10.1111/j.1752-1688.2011.00542.x

Lóczy, D.n., Czigány, S., Pirkhoffer, E., 2012. Flash flood hazards, Studies on Water Management Issues. InTech, pp. 27-52.

Macdonald, N., 2007. Epigraphic Records: A Valuable Resource in Reassessing Flood Risk and LongTerm Climate Variability. Environmental History, 12(1): 136-140. DOI:10.1093/envhis/12.1.136

Macdonald, N., Sangster, H., 2017. High-magnitude flooding across Britain since AD 1750. Hydrol. Earth Syst. Sci., 21(3): 1631-1650. DOI:10.5194/hess-21-1631-2017

MacDougall, N., 2010. Flood Risk for Extreme Events (FREE): British Rainfall Digital Archive (18671968). NCAS British Atmospheric Data Centre.

Matalas, N.C., 2012. Comment on the Announced Death of Stationarity. Journal of Water Resources Planning and Management, 138(4): 311-312. DOI:doi:10.1061/(ASCE)WR.19435452.0000215

Mediero, L. et al., 2015. Identification of coherent flood regions across Europe by using the longest streamflow records. Journal of Hydrology, 528(Supplement C): 341-360. DOI:https://doi.org/10.1016/i.jhydrol.2015.06.016

Milly, P.C.D. et al., 2008. Stationarity Is Dead: Whither Water Management? Science, 319(5863): 573-574. DOI:10.1126/science.1151915

Mishra, A.K., Coulibaly, P., 2009. Developments in hydrometric network design: A review. Reviews of Geophysics, 47(2): 1-24. DOI:doi:10.1029/2007RG000243

NERC, 1975. Flood Studies Report in Five Volumes. Natural Environment Research Council. 
O'Connell, D., Levish, D., Ostenaa, D., 1998. Risk-based hydrology: Bayesian flood-frequency analyses using paleoflood information and data uncertainties, Proc. First Federal'Interagency Hydrological Modeling Conf.

Phillips, I.D., 2003. Four south-west Birmingham flood events, 1998-2000. Weather, 58(4): 143-155. DOI:10.1256/wea.02.02

Pitt, M., 2008. The Pitt Review: Learning lessons from the 2007 floods. London: Cabinet Office, 20.

Potter, H.R., 1978. The use of historic records for the augmentation of hydrological data, Institute of Hydrology, Wallingford, UK.

Sandford, C., Illingworth, A., Thompson, R., 2017. The potential use of the linear depolarisation ratio to distinguish between convective and stratiform rainfall to improve radar rain rate estimates. Journal of Applied Meteorology and Climatology, 56: 2927-2940. DOI:10.1175/JAMC-D-17-0014.1

Shaw, J., Cudmore, S., Turner, D., Collier, D., 2005. Improving flood warning awareness in low probability and medium - high consequence flood zones. R\&D Technical Report W5-024, Environment Agency, Bristol, UK.

Stedinger, J.R., Cohn, T.A., 1986. Flood Frequency Analysis With Historical and Paleoflood Information. Water Resources Research, 22(5): 785-793. DOI:10.1029/WR022i005p00785

Stephenson, A.G., 2002. evd: Extreme Value Distributions, R News, http://CRAN.Rproject.org/doc/Rnews/pp. 31-32.

Stevens, A.J., Clarke, D., Nicholls, R.J., 2016. Trends in reported flooding in the UK: 1884-2013. Hydrological Sciences Journal, 61(1): 50-63. DOI:10.1080/02626667.2014.950581

Villarini, G., Serinaldi, F., Smith, J.A., Krajewski, W.F., 2009. On the stationarity of annual flood peaks in the continental United States during the 20th century. Water Resources Research, 45(8). DOI:doi:10.1029/2008WR007645

Wass, P., Lindsay, D., Faulkner, D., 2008. Flash Flood! A lucky escape for 10,000 bikers, Tenth British Hydrological National Symposium, Sustainable Hydrology for the 21st Century, Newcastle, UK.

Wetter, O., 2017. The Potential of Historical Hydrology in Switzerland. Hydrol. Earth Syst. Sci. Discuss., 2017: 1-31. DOI:10.5194/hess-2017-410

Williams, H., 1957. Flooding characteristics of the River Swale. Unpublished PhD thesis, University of Leeds.

Word count $=6,100$ (excluding references, tables, figures and acknowledgements) 